\title{
Peep show, road movie
}

\author{
Citation for published version (APA):
}

Stockbrügger, R. W. (1993). Peep show, road movie. Maastricht University. https://doi.org/10.26481/spe.19930624rs

Document status and date:

Published: 24/06/1993

DOI:

10.26481/spe.19930624rs

Document Version:

Publisher's PDF, also known as Version of record

\section{Please check the document version of this publication:}

- A submitted manuscript is the version of the article upon submission and before peer-review. There can be important differences between the submitted version and the official published version of record.

People interested in the research are advised to contact the author for the final version of the publication, or visit the DOI to the publisher's website.

- The final author version and the galley proof are versions of the publication after peer review.

- The final published version features the final layout of the paper including the volume, issue and page numbers.

Link to publication

\footnotetext{
General rights rights.

- You may freely distribute the URL identifying the publication in the public portal. please follow below link for the End User Agreement:

www.umlib.nl/taverne-license

Take down policy

If you believe that this document breaches copyright please contact us at:

repository@maastrichtuniversity.nl

providing details and we will investigate your claim.
}

Copyright and moral rights for the publications made accessible in the public portal are retained by the authors and/or other copyright owners and it is a condition of accessing publications that users recognise and abide by the legal requirements associated with these

- Users may download and print one copy of any publication from the public portal for the purpose of private study or research.

- You may not further distribute the material or use it for any profit-making activity or commercial gain

If the publication is distributed under the terms of Article $25 \mathrm{fa}$ of the Dutch Copyright Act, indicated by the "Taverne" license above, 
Universiteitsbibliotheek

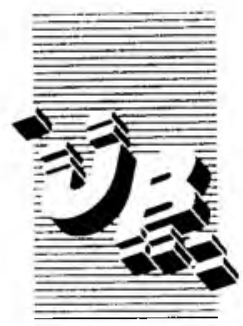

De uitleentermijn versirıkt op

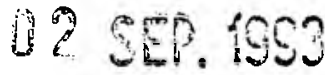

12 DEC. 2001

Rıkksuniversiteit Lımburg

Postbus 616

6200 MD Maastricht

Gelieve deze publicatie tijdig te retourneren of (telefonisch) verlenging van de vitleentermijn aan te vragen. 


\section{PEEP SHOW, ROAD MOVIE}

Rede uitgesproken bij de aanvaarding van het ambt van hoogleraar in de interne geneeskunde, in het bijzonder de gastroenterologie, aan de Rijksuniversiteit Limburg op donderdag 24 juni 1993

door

Dr. R.W. Stockbrügger 


$$
\text { ppw } 100330022
$$

Bilbliotheek
R.U. Limburg 
Mijnheer de Rector Magnificus, dames en heren hoogleraren, waarde collegae, dames en heren studenten en gij allen die deze plechtigheid met uw aanwezigheid vereert.

Het wordt hoog tijd dat ik mijn inaugurale rede houd, nu ik al bijna drie jaar het hoogleraar ambt heb mogen uitoefenen. $\mathrm{k}$ hoop dat het mij niet kwalijk wordt genomen dat ik eerst het Nederiands wilde leren en mij in de sfeer van deze universiteit en regio wilde inleven vooraleer te gaan verklaren wie ik ben, wat ik in het verleden heb gedaan en wat ik voor mijn vak en voor deze universiteit denk te gaan doen.

Een paar maanden geleden had ik het genoegen de inaugurale rede van de hooggeleerde collega Van Praag te lezen. Ik was gefascineerd door zijn openhartige zelfkarakterisatie en zich te tekenen als een hybride van een Wandelende jood en een Vliegende Hollander. Ik vroeg mij af of het aan een soortgelijke rusteloosheid was te wijten, dat ik op vele plaatsen in Europa mijn professie heb uitgeoefend voordat ik vaste voet in Maastricht kreeg. Ik ben tot de conclusie gekomen dat ik in mindere mate door rusteloosheid wordt gedreven, maar meer door nieuwsgierigheid; een nieuwsgierigheid die in hoofdzaak van tweeërlei aard is: visueel en sociaal-politiek. Ik zal mij nader verklaren. 


\section{Peep show}

De visuele nieuwsgierigheid heeft duidelijke hereditaire kenmerken. Mijn grootvader was restaurateur van schilderijen en ook zelf schilder. Toen hij door een ernstige astma al geruime tijd aan zijn huiskamer was gebonden, stuurde hij mij het Westfaalse platteland op om met een fototoestel plaatjes vast te leggen die hij als motieven voor nieuwe schilderijen kon gebruiken.

Recent heb ik begrepen dat mijn zoon Philip waarschijnlijk uit soortgelijk hout is gesneden. Luttele minuten na zijn geboorte zag ik hoe hij met wijd opengesperde ogen en febriele lust de eerste beelden van zijn nieuwe wereld opzoog.

Ikzelf was al jong een liefhebber van de beeldende kunst en waarschijnlijk was visuele lust de oorzaak waarom ik op een donkere koude winteravond in 1969 in Uppsala, Zweden, besloot een opleiding als psychiater in te ruilen voor die van een endoscopiërende internist. Het zal echter voor een ieder, die de titel van deze rede heeft gelezen en mij kent, duidelijk zijn dat ik het hiema over gastrointestinale endoscopie wil hebben; de techniek die meer dan alle andere gedurende de afgelopen decennia de gastroenterologie heeft veranderd. In mijn rede wil ik niet lang vertoeven bij algemene beschrijvingen van technische details en klinische bevindingen, maar juist proberen over te brengen dat de endoscopie zich ook heeft ontwikkeld tot een buitengewoon belangrijk research instrument. Op deze wijze denk ik het best mijn wetenschappelijke ontwikkeling, de actuele trends in de gastroenterologie en uiteraard de toekomstplannen binnen mijn werkgroep te kunnen illustreren. 


\section{Geschiedenis van de gastrointestinale endoscopie}

Ik kan niet vermijden $u$ een kort overzicht te geven over de geschiedenis van de gastro- intestinale endoscopie, dat wil zeggen het inspecteren van de binnenkant van het maag-darm stelsel bij de levende mens.

Over endoscopische pogingen in de oudheid, de middeleeuwen en de Nieuwe Geschiedenis is zeer weinig bekend. De eerste keer dat het mogelijk was het levende maagslijmvlies gedurende een langere tijd te beschouwen was niet via een instrument, maar door middel van een traumatische maag-huid fistel bij een Amerikaanse trapper, Alexis St. Martin. Zijn arts, Dr. William Beaumont, gebruikte deze chronische fistel om bij de patiënt systematisch te bestuderen welke invloed emoties en andere psycho-physische verschijnselen hadden op de doorbloeding en secretie van het genoemde slijmvlies ( 1 ); een thema dat sedertdien weinig aan actualiteit heeft verloren.

De motieven die de verdere ontwikkeling van de endoscopie hebben bepaald waren meer voor de hand liggend. Sedert het einde van de negentiende eeuw waren abdominale ingrepen mogelijk waarbij het maag-darm kanaal werd geopend. Er bestond een begrijpelijke wens bij chirurgen reeds preoperatief een exacte morfologische diagnose van de te opereren laesie te verkrijgen. De technische mogelijkheden waren sterk beperkt en daarom mengde zich gedurende lange tijd een element van acrobatiek in de geneeskunde: endoscopen waren in het begin lange starre ofwel halfstarre buizen met ingewikkelde optische systemen die het mogelijk maakten slechts beperkte gebieden van de onderste dikke darm, dat wil zeggen anus, rectum en sigmoïd, maar ook de van slokdarm en soms de maag te beschouwen. Later werden deze folterwerktuigen regelmatig technisch verbeterd ten behoeve van diagnostiek en therapie (2).

Tegenwoordig echter beleeft de endoscopie met starre instrumenten een explosieve renaissance in de vorm van de laparoscopische chirurgie. Hoogkaraatse lenssystemen met conversie van het beeld middels video-techniek worden door kleine incisies in de buikholte geïntroduceerd. Hier kunnen de chirurgen met zogenaamde 'kijkoperaties' de galblaas, de blinde darm en andere darmsegmenten verwijderen, alsmede midderirifbreuken herstellen en in de nabije toekomst waarschijnlijk ook maagzweeroperaties uitvoeren. 
De starre endoscopie was niet geschikt om ontstekingen, zweren en kleine nieuwvormingen in maag en darm te diagnostiseren. Daarom werd in de jaren na 1910 de radiologische diagnostiek geïntroduceerd (3); de zogenaamde maag-foto's en colon-inloop foto's. Met behulp van dubbel-kontrast techniek werd een dusdanige precisie bereikt dat ze heden nog in Japan worden gebruikt voor grootschalige bevolkingsonderzoeken ten behoeve van de vroegdiagnostiek van maagkanker. Helaas mankeert het bij deze methode aan de mogelijkheid weefsel te verkrijgen voor histopathologisch onderzoek.

De uiteindelijke doorbrak voor de gastrointestinale endoscopie geschiedde in 1958 toen de Zuidafrikaanse gastroenteroloog en onderzoeker Basil Hirschowitz het idee opvatte flexibele glasfiberinstrumenten, die door de industrie gebruikt werden om verborgen hoeken van motoren te kunnen inspecteren, in de veel fijnere machinerie van de mens binnen te brengen (4). Het was met één van de eerste commerciële fiberendoscopen, natuurlijk gefabriceerd door de Japanse optische industrie, dat ik in december 1970 mijn gastroenterologische peep show kon beginnen.

\section{Recente technische ontwikkelingen}

Intussen heeft een continue innovatie van het fiberoptische instrumentarium plaats gevonden. Niet onverwacht heeft hierbij de electroniek een dominerende rol gespeeld. Nadat gedurende de eerste 25 jaren de endoscopische beelden via bundels van glasfibers naar het okulaar werden overgebracht, geschiedt tegenwoordig de beeldvorming en beeldtransmissie met electronische systemen. Het peep hole is nu door de monitor vervangen. De patiënt wil liefst meekijken: gastroenterologische diagnostiek als televisie show. Recent werd aan de optische techniek van de endoscopen nog de ultrageluidstechniek toegevoegd: met deze zogenaamde echo-endoscopie is het mogelijk geworden op vele plaatsen in het maag-darm kanaal niet alleen de binnenruimte en de oppervlakte te bestuderen, maar ook de opbouw van de wand en de diepere structuren te visualiseren.

De diagnostische vooruitgang werd begeleid door even grote en snelle ontwikkelingen in het therapeutische instrumentarium dat via kleine kanalen tot in 
de slokdarm, maag of darm wordt binnengebracht en vervolgens onder zichtcontrole kan worden bediend. Dit geldt voor injectienaalden, sondes voor hitte- en lasercoagulatie, mechanische en electrische messen, hechtapparatuur, etc.

\section{Endoscopie en gastroenterologie}

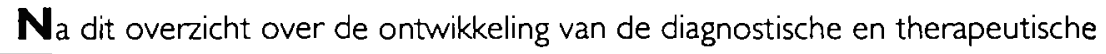
gastrointestinale endoscopie zult u begrijpen waarom in een aantal landen. waaronder Nederland, de gastroenterologie een zelfstandig medisch specialisme is geworden, meer of minder losstaand van het moederspecialisme inteme geneeskunde. Zes jaar opleiding tot internist is niet meer voldoende om alle gastroenterologische technieken te kunnen aanleren. Ik kan u verzekeren dat de tijdspanne van drie jaar voor de vervolgopleiding tot gastroenteroloog krap bemeten is om de zojuist beschreven technieken en de overige onderzoeksmethoden hetreffende de gastrointestinale secretie, bewegelijkheid, immuniteit, microbiologie, etc., volledig te leren beheersen.

De verleiding superspecialist te worden of superspecialisten op te leiden is groot gezien de schier onbegrensde technische mogelijkheden. Ikzelf zal tegen de achtergrond van langdurige werkzaamheid in de eerste lijn en binnen kleine ziekenhuizen op het platteland, waaronder vijf jaar de leiding van een gastroenterologische revalidatie kliniek, ook in de toekomst pleiten voor een nauwe samenwerking met de interne geneeskunde.

\section{Endoscopie als 'research tool'}

In dit hoofdstuk wil ik een verdere dimensie van de endoscopie toelichten, die voor mij de meest belangrijke is geworden. Ik zou dit hoofdstuk eigenlijk willen noemen: "van peep show tot visie". Het betreft de endoscopie als 'research tool'.

Toen ik 197| nog bezig was endoscopische technieken te leren en endoscopische indrukken te accumuleren vond ver weg in de Zweedse afzondering mijn persoonlijke 'Urkanall' plaats: ik las over een door Australische onderzoekers voorgestelde nieuwe indeling van de maagslijmvliesontsteking, in het Latijn 'gastritis', in de types A en B. Deze zouden te onderscheiden zijn door bepaling van de 
bloedconcentratie van het maaghormoon 'gastrine'. De onderzoekers stelden dat bij gastritis van type $A$ de hormoonproduktie hoog was ten gevolge van behouden gezond slijmvlies in het onderste gedeelte van de maag (waar dit hormoon wordt geproduceerd) in combinatie met ontremming van de gastrinecellen door gebrek aan zuursecretie als gevolg van ontsteking en atrofie in het bovenste gedeelte van de maag. Bij gastritis van het type $B$ zou daarentegen het aantal gastrinecellen in het onderste gedeelte van de maag verminderd zijn en de zuursecretie uit het bovenste gedeelte normaal.

Het toeval wilde dat een vriend en collega uit Uppsala. Gudmar Lundquist, zojuist was begonnen hormonen te bepalen met een nieuwe methode, de radioimmunoassay, waaronder ook het hormoon gastrine. Ikzelf kon door middel van endoscopie weefselbrokjes uit verschillende maaggebieden nemen voor histologische analyse. Een andere collega, Lars-Inge Larsson uit Lund, was ervaren in het aankleuren van de gastrine cellen in slijmvliesbiopten. Om het kort te maken, ruim vier jaar later konden wij in een proefschrift de Australische hypothese van de twee types gastritis bevestigen (5). Ik had geleerd, dat de gastrointestinale endoscopie niet alleen een uiterst waardevolle klinische methode was, maar tegelijkertijd een haast onbeperkt instrument ten behoeve van wetenschappelijk onderzoek.

De endoscopie bleek niet alleen geschikt te zijn voor het verkrijgen van grote aantallen slijmvliesmonsters, maar ook voor het observeren van de maag-darm beweeglijkheid, het opzuigen van slijm en sekreet, het inbrengen van meetinstrumenten, en een veelvoud aan andere technieken. Dit alles kan geschieden ofwel in het kader van diagnostisch routine onderzoek zonder additionele belasting voor de patiënt, ofwel bij gezonde vrijwilligers, mits de onderzoeker de endoscopische technieken op juiste wijze hanteert.

\section{Voorbeelden}

De omvang van de endoscopische research mogelijkheden wil ik $u$ in het kort illustreren aan de hand van een serie interessante resultaten die gedurende de laatste twintig jaar werden bereikt door collegae in mijn nabije omgeving ofwel door vrienden en medewerkers op verschillende plaatsen in Europa. 
Barrett slijmvlies. Mijn medewerker en plaatsvenanger hier in Maastricht Dr. Wim Hameeteman heeft tesamen met onder andere professor Tytgat uit het Academisch Medisch Centrum in Amsterdam een omvangrijke endoscopisch-bioptische studie uitgevoerd naar het zogenaamde Barrett slijmvlies in de onderste slokdarm (6). Dit is een toestand waarbij het normaal in dit gebied aanwezige slijmvlies vervangen wordt door maagdarm type slijmvlies. Patiënten met Barrett slijmvlies hebben een verhoogd risico op de ontwikkeling van slokdarmkanker.

Wim Hameeteman heeft door zorgvuldige telling en karakterisatie van weefselveranderingen bij 50 patiënten met Barrett slijmvlies in longitudinale studies kunnen vaststellen, dat patiënten met deze aandoening een risico op kanker hebben, dat 125 maal hoger is dan dat van een controle populatie.

Dit getal onderstreept het grote belang van planning van endoscopische controle programma's in deze patiëntengroep.

Coeliakie. Mijn collegae Rolf Gillberg en Christer Åhrén in Göteborg hebben in 1977 beschreven dat het door middel van endoscopie verkrijgen van multipele weefselmonsters uit de twaalfvingerige darm evenzo goed is voor het stellen van de diagnose darmspruw ofwel coeliakie - een belangrijke ziekte van de dunne darm - als de vroeger gebruikelijke en technisch moeilijke capsulebiopten uit diepere delen van de dunne darm (7). De laatstgenoemde methode was met name vervelend voor kinderen, die juist relatief vaak door coeliakie worden getroffen. De endoscopisch-histologische diagnose van deze dunne darm ziekte is tegenwoordig wereldwijd de standaard. Attractief is verder de mogelijkheid om bij overgevoeligheid van het dunne darm slijmvlies voor voedingsstoffen of andere substanties deze reacties endoscopisch op de plek des onheils te kunnen bestuderen.

Pancreas divisum. Niet alleen het maag-darm stelsel, maar ook de nabijgelegen alvleesklier en galwegen werden door middel van endoscopie toegankelijk voor onderzoek. Hierbij wordt gebruikt gemaakt van een gecombineerde endoscopische en radiologische methode, de ERCP, die een intensieve training van de onderzoeker vereist. Met behulp van deze techniek heeft mijn endoscopische leermeester Peter Cotton, toen nog in Londen, bij het endoscopische onderzoek van patiënten met alvleesklierontsteking, 'pancreatitis', 
kunnen aantonen dat personen met een ontogenetische variëteit van de alvleesklieropbouw, het zogenaamde 'pancreas divisum', ten opzichte van controlegroepen een verhoogde kans hebben op acute alvleesklier-ontsteking (8). De betekenis van deze bevinding wordt duidelijk als wij ons realiseren dat circa 5 tot 10 procent van de bevolking wordt geboren met deze variëteit 'pancreas divisum'. Gelukkig kunnen tegenwoordig patiënten met herhaalde alvleesklier ontstekingen op basis van een pancreas divisum ook endoscopisch worden behandeld. Door splijten van een kleine pancreasgang uitmonding in de twaalfvingerige darm en het vervolgens inbrengen van een kunststofbuisje komt een betere afvloed van het pancreassecreet tot stand.

Primair scleroserende cholangitis. Een ander raadsel binnen de gastroenterologie en hepatologie, aan wiens oplossing de endoscopie belangrijk heeft bijgedragen, is de zogenaamde 'primaire scleroserende cholangitis' (PSC). Dit is een chronische ontsteking van de galwegen, waarbij $85 \%$ van de patiënten met deze aandoening tegelijkertijd aan chronische dikke darm ontsteking lijden. De preciese relatie tussen beide ziektebeelden is lange tijd onduidelijk geweest.

In Göteborg had mijn vriend Dr. Bemhard laup grote belangstelling voor de combinatie van lever- en darmziekten. Gemeenschappelijk met andere hepatologen en radiologen hebben wij toendertijd met behulp van endoscopisch onderzoek van de dikke darm en de genoemde ECRP techniek bij een aantal patiënten kunnen aantonen, dat het klinische beloop van de lever-en galwegaandoening bij PSC vrijwel onafhankelijk is van de graad van endoscopisch zichtbare galwegveranderingen (9). Nog belangrijker was dat wij, in overeenstemming met andere onderzoekers, vaststelden dat het chirurgische verwijderen van de chronisch ontstoken dikke darm niet bijdraagt aan de verbetering van de galwegaandoening. Dit resultaat heeft ertoe geleid dat bij vele jonge patiënten een onnodige handicap kon worden vermeden.

Dikke darm kanker. Dikke darm kanker is een modeme plaag voor de mensheid en staat in Nederland op de derde plaats als maligne doodsoorzaak bij mannen en op de tweede plaats bij vrouwen. Nadat ik al vroeger endoscopisch onderzoek had gedaan met betrekking tot voorstadia van kanker bij chronische ontsteking van de dikke darm werd mijn belangstelling nog verder gewekt door een endoscopisch onderzoek verricht in Noorwegen door Dr. Geir Hoff en zijn collegae (10). Zij hadden in een kleine Noorse stad 400 inwoners in de leeftijd van 
50 tot 59 jaar uitgenodigd een flexibele sigmoïdoscopie, dat wil zeggen onderzoek van de dikke darm tot circa $60 \mathrm{~cm}$, te ondergaan. $81 \%$ van de opgeroepen bevolking gaf aan deze oproep gevolg. Dr. Hoff vond bij bijna een derde deel van deze 324 personen zogenaamde adenomen: goedaardige tumoren die echter het belangrijkste voorstadium vormen van toekomstige darmkanker.

De groep van Dr. Hoff trachtte ook risicofactoren ten aanzien van deze premaligne veranderingen te identificeren, hoofdzakelijk op het gebied van voeding. $\mathrm{Zij}$ vonden dat mensen met colonadenoom statistisch gezien minder vezel en groenten aten.

Deze resultaten waren aanleiding voor mijn vriend en collega Ulrich Armbrecht en mij om in Bad Kissingen, Beieren, waar wij samen een kliniek voor revalidatie van maag-, darm- en stofwisselingsziekten leidden, een nog groter onderzoek te starten op dit voor de gezondheidszorg uitermate belangrijk gebied. Wij vonden bij 146 (22.2\%) van totaal 658 symptoomvrije patiënten tussen 50 en 60 jaar adenomateuze poliepen en hebben de bevindingen onlangs in samenwerking met onze jonge collega Adang hier in Maastricht en met de vakgroep Medische Informatica en Statistiek kunnen analiseren.

Verhoogde triglyceride waarden in het bloed en rijkelijk gebruik van alcohol en sigaretten alsmede stijgende leeftijd zijn de dominerende risicofactoren gekoppeld aan de potentieel gevaarlijke colonpoliepen. Helaas is dit slecht nieuws voor de modale sympathieke Limburger, maar ook voor mijzelf omdat ik vaak moeite heb met de statistische strijd in mijn ziel tussen een kort plezierig en een lang gezond leven. Tot mijn genoegen kon ook deze onderzoekslijn, de oorzaak en ontwikkeling van dikke darmtumoren, hier in Maastricht worden doorgezet, daar er uitgebreide expertise bestaat bij verschillende vakgroepen binnen de onderzoeksmatrix.

Gastrointestinale bacteriologie. Na deze potpourri van endoscopisch onderzoek zult $u$ zich afvragen hoe het is gegaan met mijn oorspronkelijke onderwerp, de gastritis. Ik wil het $u$ graag vertellen. $1 k$ heb het onderwerp nooit meer verlaten. Met endoscopische, patho-histologische, microbiologische, biochemische en epidemiologische methoden hebben wij het vraagstuk bestudeerd betreffende de samenhang tussen gastritis, maagzuursecretie. groei van bacteriën in de maag, bacteriële produktie van kankerverwekkende substanties, 
kankervoorstadia en de mogeiijkheden de maligne ontaardiging van het maagslijmvlies te voorkómen (| |).

Dit onderzoek heeft zich in verscheidene ziekenhuizen en laboratoria rondom in Europa afgespeeld en is gedurende de laatste drie jaren uitgegroeid tot één van de hoofdthemata van onze werkgroep hier in Maastricht. Binnen de Interne Geneeskunde waren al Professor Flendrig en Dr. Loffeld bezig de rol te onderzoeken die een ander bacterie, de Helicobacter pylori, zou kunnen spelen bij diverse maagziekten.

Binnen de vakgroepen pathologie en microbiologie met collegae Prof. Arends en Dr. Stobberingh vond ik direct gehoor voor het continueren van mijn specifieke onderzoekslijn. Binnen korte tijd heeft zich een groep enthousiaste mensen gevormd die gemeenschappelijk probeert licht in de vraag te brengen of bacteriën en bacterieprodukten de oorzaak kunnen zijn van de vorming van kanker in de maag.

Dames en heren, als jonge dokter was het altijd mijn droom de weg te mogen betreden van kijken tot begrijpen. Ik kan aan u bekennen dat zich deze droom in Maastricht goed laat dromen. 


\section{Road movie}

Na deze uitleg over het beschouwen van de binnenkant, de endoscopie, wil ik u nog kort berichten over de andere dimensie van mijn nieuwsgierigheid, de geografisch-sociaal-politieke, de film van het leven. Deze film is de laatste 25 jaren hoofdzakelijk in zes Europese landen opgenomen; een typische 'road movie'. Gezien dit gegeven verbaast het eigenlijk niemand dat ik in Maastricht terecht moest komen.

Gevraagd naar het motief van mijn reis vermoed ik als hoofdoorzaak een overmatige drang naar vrijheid. Gedurende mijn jeugd in Duitsland ondervond ik de diepe indruk van de verwoestende consequenties, die nationalistische en antiintellectuele isolatie kunnen hebben. $\mathrm{kk}$ heb sedertdien geprobeerd deze grenzen achter mij te laten.

Wat waren de winsten? Het is onmogelijk deze op te tellen en het zou ook hun schoonheid laten verbleken. I $k$ heb in ieder geval een schat aan medeacteuren, kulissen, requisieten, draaiboeken en muziek mogen verzamelen, die ik als een immense rijkdom ervaar. Eén van de grote belevenissen vond ik dat het mogelijk was, puur met je ideeën, je enthousiasme en je kennis een land, een stad, een ziekenhuis binnen te lopen en zo te kunnen beginnen met de behandeling van patiënten, met het onderzoek en met de rest van de gewone dag.

Ik heb al lang aan den lijve ondervonden dat Europa mogelijk is en ik zal mijn uiterste best blijven doen om deze ervaring aan de omgeving over te dragen. Wat dit betreft wil ik graag het woord in het bijzonder tot u richten, dames en heren studenten. Vergeleken met de reizen van uw landgenoot Erasmus lijken mijn reizen op een zondagse wandeling. Maar als velen van u op deze wijze beginnen de grenzen te overschrijden kan de grote Europese renaissance van bijna 500 jaar geleden misschien nogmaals plaatsvinden. $U$ hebt de kans en ik heb met genoegen gezien dat $u$ in grote getalen ervan gebruik begint te maken. $l k$ ben graag bereid $u$ bij het plannen van de route als gids bij te staan. 
$\overline{s .0}$ 


\section{Dank}

Als ik nu zal bedanken voor peepshow en road movie zo staat vanzelfsprekend mijn moeder op de eerste plaats. Zij heeft mijn ogen geopend en mij laten zien dat wat zijzelf nooit heeft mogen zien en envaren.

Mijn leermeesters hebben in mij de lusten gewekt van zoeken, zien, verwonderd zijn, begrijpen en scheppen. Zij waren met velen. Hier is een nuchtere en incomplete lijst van namen, die voor mij een leven zijn geweest:

- Lennart Angervall

- Mikulas Hradsky

- Joachim van Appen

- Gudmar Lundquist

- Albert Camus

- Leo Meurman

- Peter B. Cotton

- Eduard Rothfuchs

- Gerhard Dotevall

- Henri Sarles.

Collegae, medewerkers, patiënten en studenten in vijf landen hebben mij alle tolerantie, vertrouwen, steun en opmontering gegeven, die nodig zijn als je onderweg bent op onbekend terrein.

Zeergeleerde Brummer, beste Robert-Jan, jij hebt met je fijne neus bemerkt dat Maastricht de goede plek voor mij zou zijn om tijd en rust te vinden voor het monteren van de film. Mijn diepe dank aan jou. Dank ook voor je hulp bij het voorbereiden van deze tekst.

Aan de leden van de benoemingscommissie, met de hooggeleerde Soeters vooraan, mijn dank voor twee goede gesprekken. Zij hebben mij de beste samenwerking beloofd. Zij hebben hun woord gehouden. 
Het College van Bestuur van de Rijksuniversiteit Limburg, het Bestuur van de Faculteit der Geneeskunde van deze Universiteit en de Raad van Bestuur van het academisch ziekenhuis Maastricht hebben verantwoordelijke taken aan iemand overgelaten, die in Nederland totaal onbekend was. lk zal mij cok verder volledig inzetten om het vertrouwen niet te beschamen.

Hooggeleerde Flendrig, beste Guus en jij, beste José, laat mij vanuit deze plaats mijn dank uitspreken voor de wijze waarop jullie beiden mijn familie en mij hier in Maastricht een warm welkom hebben geheten.

In de afgelopen drie jaar is er binnen en buiten de werkgroep gastroenterologiehepatologie een team gegroeid dat met groot enthousiasme mijn klinische en wetenschappelijke ideeën heeft opgenomen en daaraan veel eigens heeft toegevoegd. ledere dag met deze groep is voor mij een plezier.

Dames en heren, een reis zoals de mijne doe je niet graag alleen. Gelukkig zijn er altijd medereizigers geweest, familie, vrienden en anderen. Velen zijn achtergebleven. Slechts een minderheid is vandaag hier aanwezig; de diep getrouwen. Twee waren het meest volhardend; Stephanie en Graziana Stockbrügger. Thanks a lot!

Hiermee heb ik gezegd. Ik dank u voor uw aandacht. 


\section{Geraadpleegde literatuur}

1.

Beaumont $W$. Experiments and observations on the gastric juice and the physiology of digestion. F.P. Allen, Plattsburgh 1833.

2. Schindler R. Ein völlig ungefährliches, flexibles Gastroskop. Münchener Medizinische Wochenschrift 1932; 79: 1268-1269.

3. Reiche F. Zur Diagnose des Ulcus ventriculi im Röntgenbild. Fortschritte auf dem Gebiete der Röntgenstrahlen 1910; 14: 171-173.

4. Hirschowitz $\mathrm{Bl}$ et al. Demonstration of a new gastroscope, the "fiberscope". Gastroenterology 1958; 35: 50-53.

5. Stockbrügger R. Aspects of chronic atrophic gastritis with special reference to serum gastrin and antral gastrin cells. Thesis, Gothenburg 1976.

6. Hameeteman W. Columnar lined (Barrett's) esophagus. Thesis, Amsterdam 1989.

7. Gillberg R, Ảhren C. Coeliac disease diagnosed by means of duodenoscopy and endoscopic duodenal biopsies. Scandinavian joumal of Gastroenterology 1977: 12: 911-916.

8. Cotton PB. Congenital anomaly of pancreas divisum as cause of obstructive pain and pancreatitis. Gut 1980; 21: 105-114.

9. Stockbrügger RW et al. Forty-six patients with primary sclerosing cholangitis: radiological bile duct changes in relationship to clinical course and concomitant inflammatory bowel disease. Hepato-Gastroenterology 1988; 35: 289-294. 
10. Hoff $G$ et al. Epidemiology of polyps in the rectum and sigmoid colon in a population of men and women aged 50-59 years old. Thesis, Oslo 1986.

II. Stockbrügger RW, Jaup BH. Intragastric bacterial overgrowth - a possible risk in the long-term treatment of peptic ulcer disease. Scandinavian Joumal of Gastroenterology 1985; 20: suppl. I I I. 